\title{
Article
}

\section{Nanoshell Magnetic Resonance Imaging Contrast Agents}

Chia-Hao Su, Hwo-Shuenn Sheu, Chia-Yun Lin, Chih-Chia Huang, Yi-Wei Lo, Ying-Chih Pu, Jun-Cheng Weng, Dar-Bin Shieh, Jyh-Horng Chen, and Chen-Sheng Yeh J. Am. Chem. Soc., 2007, 129 (7), 2139-2146• DOI: 10.1021/ja0672066• Publication Date (Web): 31 January 2007

Downloaded from http://pubs.acs.org on March 3, 2009

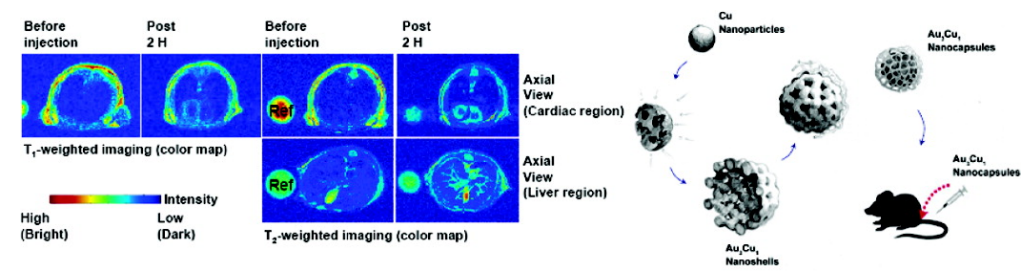

\section{More About This Article}

Additional resources and features associated with this article are available within the HTML version:

- Supporting Information

- Links to the 12 articles that cite this article, as of the time of this article download

- Access to high resolution figures

- $\quad$ Links to articles and content related to this article

- $\quad$ Copyright permission to reproduce figures and/or text from this article

\section{View the Full Text HTML}




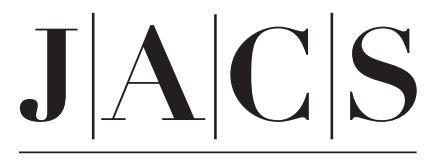

A R T I C L E S

Published on Web 01/31/2007

\title{
Nanoshell Magnetic Resonance Imaging Contrast Agents
}

\author{
Chia-Hao Su, ${ }^{\dagger \neq}+$ Hwo-Shuenn Sheu, ${ }^{\S}$ Chia-Yun Lin, ${ }^{\dagger}$ Chih-Chia Huang, ${ }^{\dagger}$ Yi-Wei Lo, ${ }^{\dagger}$ \\ Ying-Chih Pu, ${ }^{\dagger}$ Jun-Cheng Weng, ${ }^{\ddagger}$ Dar-Bin Shieh, ${ }^{\perp}$ Jyh-Horng Chen, ${ }^{*}, \neq$ and \\ Chen-Sheng Yeh*,
}

Contribution from the Department of Chemistry and Center for Micro/Nano Science and Technology and Institute of Oral Medicine and Molecular Medicine, National Cheng Kung University, Tainan 701, Taiwan, Interdisciplinary MRI/MRS Lab, Department of Electrical Engineering, National Taiwan University, Taipei 106, Taiwan, and National Synchrotron Radiation Research Center, Hsinchu 30076, Taiwan

Received October 8, 2006; E-mail: csyeh@mail.ncku.edu.tw; chen@me.ee.ntu.edu.tw

\begin{abstract}
Nanocontrast agents have great potential in magnetic resonance (MR) molecular imaging applications for clinical diagnosis. We synthesized $\mathrm{Au}_{3} \mathrm{Cu}_{1}$ (gold and copper) nanoshells that showed a promising MR contrast effect. For in vitro MR images, the large proton $r_{1}$ relaxivities brightened $T_{1}$-weighted images. As for the proton-dephasing effect in $T_{2}, \mathrm{Au}_{3} \mathrm{Cu}_{1}$ lightened MR images at the low concentration of $0.125 \mathrm{mg} \mathrm{mL}^{-1}\left(3.84 \times 10^{-7} \mathrm{mM}\right)$, and then the signal continuously decreased as the concentration increased. For in vivo MR imaging, $\mathrm{Au}_{3} \mathrm{Cu}_{1}$ nanocontrast agents enhanced the contrast of blood vessels and suggested their potential use in MR angiography as blood-pool agents. We propose that (1) the cooperativity originating from the form of the nanoparticles and (2) the large surface area coordinated to water from their porous hollow morphology are important for efficient relaxivity. In a cytotoxicity and animal survival assay, $\mathrm{Au}_{3} \mathrm{Cu}_{1}$ nanocontrast agents showed a dose-dependent toxic effect: the viability rate of experimental mice reached $83 \%$ at a dose of $20 \mathrm{mg} \mathrm{kg}^{-1}$ and as much as $100 \%$ at $2 \mathrm{mg} \mathrm{kg}^{-1}$.
\end{abstract}

\section{Introduction}

Nanoparticle systems are promising new paradigms in pharmacotherapy and are being used in gene therapy, drug delivery, ${ }^{1,2}$ imaging, ${ }^{3,4}$ and novel drug discovery techniques. ${ }^{5,6}$ The aim of nanodiagnostics is to identify disease at its earliest stage, particularly at the molecular level. Nanoparticle-based molecular imaging has set a unique platform for cellular tracking, targeted diagnostic studies, and image-monitored therapy. ${ }^{7-10}$ Magnetic resonance imaging (MRI) has been recognized as the most

$\dagger$ Department of Chemistry and Center for Micro/Nano Science and Technology, National Cheng Kung University.

Interdisciplinary MRI/MRS Lab, Department of Electrical Engineering, National Taiwan University.

$\S$ National Synchrotron Radiation Research Center.

${ }^{\perp}$ Institute of Oral Medicine and Molecular Medicine, National Cheng Kung University.

(1) Shaffer, C. Drug Discovery Today 2005, 10, 1581-1582.

(2) Vinogradov, S. Expert Opin. Drug Delivery 2004, 1, 181-184.

(3) Muldoon, L. L.; Tratnyek, P. G.; Jacobs, P. M.; Doolittle, N. D.; Christoforidis, G. A.; Frank, J. A.; Lindau, M.; Lockman, P. R.; Manninger, S. P.; Qiang, Y.; Spence, A. M.; Stupp, S. I.; Zhang, M.; Neuwelt, E. A. AJNR Am. J. Neuroradiol. 2006, 27, 715-721.

(4) Li, K. C.; Pandit, S. D.; Guccione, S.; Bednarski, M. D. Biomed. Microdevices 2004, 6, 113-116.

(5) Wilkinson, J. M. Med. Device Technol. 2003, 14, 29-31.

(6) Roco, M. C. Curr. Opin. Biotechnol. 2003, 14, 337-346.

(7) Winter, P. M.; Morawski, A. M.; Caruthers, S. D.; Fuhrhop, R. W.; Zhang, H.; Williams, T. A.; Allen, J. S.; Lacy, E. K.; Robertson, J. D.; Lanza, G. M.; Wickline, S. A. Circulation 2003, 108, 2270-2274.

(8) Krause, M. H.; Kwong, K. K.; Gragoudas, E. S.; Young, L. H. Magn. Reson. Imaging 2004, 22, 779-787.

(9) Bulte, J. W.; Zhang, S.; van Gelderen, P.; Herynek, V.; Jordan, E. K.; Duncan, I. D.; Frank, J. A. Proc. Natl. Acad. Sci. U.S.A. 1999, 96, 1525615261.

(10) Anderson, S. A.; Glod, J.; Arbab, A. S.; Noel, M.; Ashari, P.; Fine, H. A.; Frank, J. A. Blood 2005, 105, 420-425

10.1021/ja0672066 CCC: $\$ 37.00$ @ 2007 American Chemical Society important technique in medical diagnosis since the discovery of the X-ray. MRI measures the characteristics of the hydrogen nuclei of water and shows the spatial distribution of the intensity of water protons. The signal intensity depends on the amount of water in the image area. Contrast agents accelerate the rate of relaxation of nearby water molecules, thereby greatly increasing the contrast between the specific tissue or organ of interest and its surrounding tissue. Effective magnetic resonance (MR) contrast agents must have a strong effect to accelerate spin-lattice relaxation $\left(T_{1}\right)$, which produces bright or positivecontrast images, or to shorten spin-spin relaxation $\left(T_{2}\right)$, which produces dark or negative-contrast images. Currently, MR contrast agents are categorized into $T_{1}$-positive agents of paramagnetic species and $T_{2}$-negative agents of superparamagnetic particles. The paramagnetic $T_{1}$ agents include gadolinium $\left(\mathrm{Gd}^{3+}\right)$-, manganese $\left(\mathrm{Mn}^{2+}\right)$-, chromium $\left(\mathrm{Cr}^{3+}\right)$-, lanthanide $\left(\mathrm{Ln}^{3+}\right)$-, and dysprosium $\left(\mathrm{Dy}^{3+}\right)$-based complexes ${ }^{11-16}$ and gadolinium-encapsulated liposomes. ${ }^{17,18}$ Because these para-

(11) Ho, C.; Hitchens, T. K. Curr. Pharm. Biotechnol. 2004, 5, 551-566.

(12) Natanzon, A.; Aletras, A. H.; Hsu, L. Y.; Arai, A. E. Radiology 2005, $236,859-866$.

(13) Ahn, J. H.; Yoo, C. I.; Lee, C. R.; Lee, J. H.; Lee, H.; Kim, C. Y.; Park, J. K.; Sakai, T.; Yoon, C. S.; Kim, Y. Neurotoxicology 2003, 24, 835838.

(14) Jackson, G. E.; Byrne, M. J.; Blekkenhorst, G.; Hendry, A. J. Int. J. Radiat. Appl. Instrum., Part B 1991, 18, 855-858.

(15) Aime, S.; Crich, S. G.; Gianolio, E.; Giovenzana, G. B.; Tei, L.; Terreno, E. Coord. Chem. Rev. 2006, 250, 1562-1579.

(16) Fossheim, S.; Saebo, K. B.; Fahlvik, A. K.; Rongved, P.; Klaveness, J. J. Magn. Reson. Imaging 1997, 7, 251-257.

(17) Sipkins, D. A.; Cheresh, D. A.; Kazemi, M. R.; Nevin, L. M.; Bednarski, M. D.; Li, K. C. Nature Med. 1998, 4, 623-626.

(18) Kabalka, G.; Buonocore, E.; Hubner, K.; Moss, T.; Norley, N.; Huang, L. Radiology 1987, 163, 255-258. 
Scheme 1. $\mathrm{Au}_{3} \mathrm{Cu}_{1}$ Nanocapsules Used as Contrast Agents in Animal MR Imaging

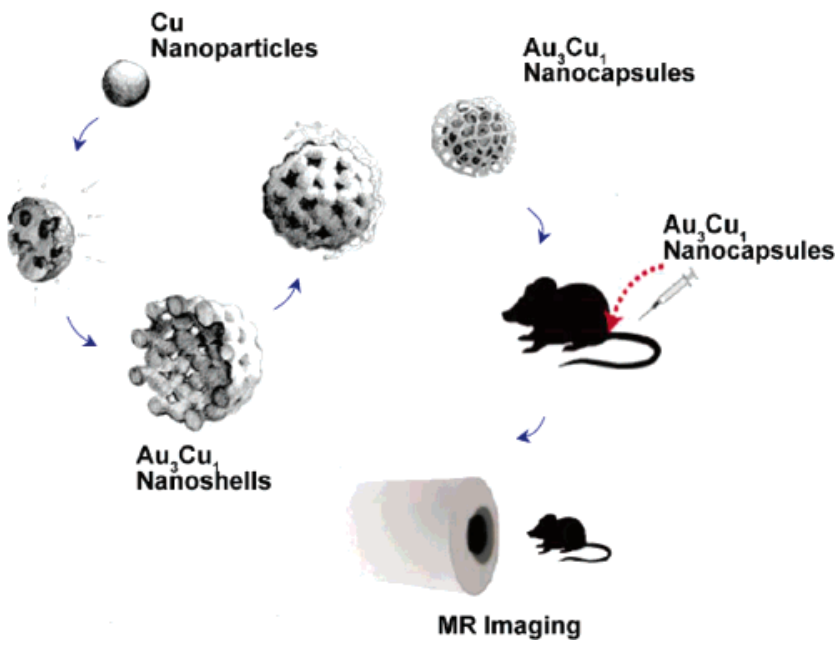

magnetic ions are inherently toxic and cannot be directly injected into or ingested by patients, they are administered as chelates, formed when they bind to ligands such as diethyltriamine pentaacetic acid (DTPA), 1,4,7,10-tetraazacyclododecane$N, N^{\prime}, N^{\prime \prime}, N^{\prime \prime \prime}$-tetraacetic acid, and ethylenediamine tetraacetic acid, to achieve the desired biodistribution and ensure patient safety. Recently, some Gd-based nanoparticle contrast agents have also been reported. ${ }^{19-22}$ The superparamagnetic particles ( $T_{2}$-negative agents) are nanosized or submicrometer-sized and are classified as superparamagnetic iron oxide (SPIO), ultrasmall SPIO, or monocrystalline iron oxide nanoparticles. ${ }^{23,24}$ Superparamagnetic particles consist of many magnetic ions with significant, large, unpaired spins; they are superparamagnetic when the magnetic ions are mutually aligned. In the present study, we present a new class of bimetallic MR contrast agent: $\mathrm{Au}_{3} \mathrm{Cu}_{1}$ hollow nanospheres (Scheme 1).

\section{Experimental Section}

Preparing $\mathrm{Cu}$ Nanoparticles. We generated $\mathrm{Cu}$ nanoparticles using a laser to irradiate $\mathrm{CuO}$ powder in 2-propanol. Pyrex vials were used as containers to prepare the colloidal solutions. An unfocused Nd:YAG laser (Quantel Brilliant) operated at $10 \mathrm{~Hz}$ (5-ns pulse width) with a wavelength of $1064 \mathrm{~nm}$ was inserted into the vials containing $0.015 \mathrm{~g}$ of $\mathrm{CuO}$ powder and $5 \mathrm{~mL}$ of 2-propanol. The $\mathrm{Cu}$ colloidal solutions were prepared as follows: the mixture was irradiated at a laser intensity of $100 \mathrm{~mJ} /$ pulse for $5 \mathrm{~min}$. The irradiated mixture was then centrifuged to remove the remaining $\mathrm{CuO}$ powder. The prepared solutions were irradiated for an additional $5 \mathrm{~min}$. The resulting $\mathrm{Cu}$ colloidal solutions had a deep wine-red color. The ablated solutions were routinely stirred every 1 min during irradiation.

Preparing $\mathrm{Au}_{3} \mathrm{Cu}_{1}$ Nanoshells and Polyelectrolyte-Coated $\mathrm{Au}_{3} \mathrm{Cu}_{1}$ Nanocapsules. $\mathrm{Cu}$ colloidal solution $(4.5 \mathrm{~mL})$ was added to $1 \times 10^{-6}$

(19) Evanics, F.; Diamente, P. R.; van Veggel, F. C. J. M.; Stanisz, G. J.; Prosser, R. S. Chem. Mater. 2006, 18, 2499-2505

(20) Lin, Y. S.; Hung, Y.; Su, J. K.; Lee, R.; Chang, C.; Lin, M. L.; Mou, C. Y. J. Phys. Chem. B 2004, 108, 15608-15611.

(21) Reynolds, C. H.; Annan, N.; Beshah, K.; Huber, J. H.; Shaber, S. H.; Lenkinski, R. E.; Wortman, J. A. J. Am. Chem. Soc. 2000, 122, 89408945.

(22) Rieter, W. J.; Taylor, K. M.; An, H.; Lin, W.; Lin, W. J. Am. Chem. Soc. 2006, 128, 9024-9025.

(23) Harisinghani, M. G.; Barentsz, J.; Hahn, P. F.; Deserno, W. M.; Tabatabaei, S.; van de Kaa, C. H.; de la Rosette, J.; Weissleder, R. N. Engl. J. Med. 2003, 348, 2491-2499.

(24) Shieh, D. B.; Cheng, F. Y.; Su, C. H.; Yeh, C. S.; Wu, M. T.; Wu, Y. N.; Tsai, C. Y.; Wu, C. L.; Chen, D. H.; Chou, C. H. Biomaterials 2005, 26, $7183-7191$ mol of $\mathrm{HAuCl}_{4}$ (dehydrated) and was sonicated for $10 \mathrm{~min}$ to form $\mathrm{Au}_{3} \mathrm{Cu}_{1}$ hollow nanospheres. The colloidal color changed almost immediately $(<1 \mathrm{~min})$ from wine-red to grayish blue after it had been added to the $\mathrm{HAuCl}_{4}$. We added $5 \mathrm{~mL}$ of 2-propanol to dilute the $\mathrm{Au}_{3}-$ $\mathrm{Cu}_{1}$ colloidal solution before coating polymers with the biocompatible polyelectrolytes polyethylenimine (PEI) and poly(acrylic acid) (PAA). We used a layer-by-layer method ${ }^{25}$ to prepare the PEI/PAA/PEI-coated $\mathrm{Au}_{3} \mathrm{Cu}_{1}$ nanocapsules. $\mathrm{Au}_{3} \mathrm{Cu}_{1}$ colloidal solution $(9.5 \mathrm{~mL})$ was mixed with $100 \mu \mathrm{L}$ of PEI (1 mM in 2-propanol, MW: 25000$)$ and stirred for $4 \mathrm{~h}$. PEI formed the innermost layer of the polymer shells that coated the $\mathrm{Au}_{3} \mathrm{Cu}_{1}$ nanoshells. The PEI-coated $\mathrm{Au}_{3} \mathrm{Cu}_{1}$ nanocapsules were collected using centrifugation (11 $000 \mathrm{rpm}$ for $7 \mathrm{~min}$ ) and then washed twice with 2-propanol to remove residual PEI. The nanocapsules were then redispersed in $9.5 \mathrm{~mL}$ of 2-propanol. Next, $100 \mu \mathrm{L}$ of PAA (10 $\mathrm{mM}$ in 2-propanol, MW: 2000) was added, and the mixture was stirred for another $16 \mathrm{~h}$. PEI/PAA-coated $\mathrm{Au}_{3} \mathrm{Cu}_{1}$ nanocapsules were then obtained after centrifugation (11 $000 \mathrm{rpm}$ for $7 \mathrm{~min}$ ) and washing. We repeated the PEI-coating steps for the final PEI layer.

Preparing $\mathbf{A u}_{7} \mathbf{A g}_{3}$ Nanoshells. The templating Ag nanoparticles and $\mathrm{Au}_{7} \mathrm{Ag}_{3}$ nanoshells were prepared using a previously reported method. ${ }^{26}$ To synthesize Ag nanoparticles, $99.8 \% \mathrm{AgNO}_{3}(0.025 \mathrm{~g})$ and poly(vinylpyrrolidone) (PVP) (0.10 g, MW: 55 000) were dissolved in $99.5 \%$ ethylene glycol $(10 \mathrm{~mL})$. The mixture was heated in a 160 ${ }^{\circ} \mathrm{C}$ oil bath for $1.5 \mathrm{~h}$ and constantly vigorously stirred. After the colloidal $\mathrm{Ag}$ solution was cooled to room temperature, $1.25 \mathrm{~mL}$ of it was added to $25 \mathrm{~mL}$ of deionized water. The resulting aqueous suspension was refluxed for $10 \mathrm{~min}$, and then $3 \mathrm{~mL}$ of a $1 \mathrm{mM} \mathrm{HAuCl}_{4} \cdot 3 \mathrm{H}_{2} \mathrm{O}$ aqueous solution was added in drops. The reaction mixture was continuously refluxed for another $15 \mathrm{~min}$ until the color became stable. Vigorous magnetic stirring was maintained throughout the synthesis. When the reaction was completed, the nanoshells were collected using centrifugation at $10000 \mathrm{rpm}$ for $15 \mathrm{~min}$ and then washed with a saturated solution of $99.9 \% \mathrm{NaCl}$ to remove the $\mathrm{AgCl}$ solid byproduct. These purification steps were repeated more than three times. Finally, the $\mathrm{Au}_{7} \mathrm{Ag}_{3}$ hollow spheres were rinsed with water several times and deposited on the silicon substrates for scanning electron microscopy (SEM) analysis without coated platinum $(\mathrm{Pt})$.

X-ray Absorption Near-Edge Spectroscopy (XANES) Measurements. X-ray absorption spectra of $\mathrm{Au}_{3} \mathrm{Cu}_{1}$ and $\mathrm{Au}_{7} \mathrm{Ag}_{3}$ at the $\mathrm{Cu} \mathrm{K}$ edge and $\mathrm{Au} \mathrm{L}_{\mathrm{III}}$ edges were measured at BL17C1 and BL01C, respectively, at the National Synchrotron Radiation Research Center in Taiwan. The spectra were recorded in transmission mode using monochromatic radiation obtained from double-crystal ( $\mathrm{Si}(111))$ monochromators and a high-harmonic-rejecting mirror. Measurements were made on powdered samples at room temperature.

Evaluating the Biocompatibility of $\mathrm{Au}_{3} \mathrm{Cu}_{1}$ Nanocapsules and Nanoshells Coated with PEI/PAA/PEI Polymers. We used a WST-1 assay ${ }^{27}$ on a Vero cell line to measure mitochondrial dehydrogenase activity known to be associated with cell viability. This assay is based on the formation of dark-red formazan by the metabolically active cells after their exposure to WST-1 (tetrazolium salt). The amount of formazan is related directly to the number of metabolically active cells in the medium and can be quantified by measuring its absorbance using an ELISA reader. The absorbance of formazan dye solution is in direct proportion to the number of viable cells. Two methods were used to evaluate the cytotoxicity of the synthesized $\mathrm{Au}_{3} \mathrm{Cu}_{1}$ nanocapsules and nanoshells in vitro. Method I: The Vero cells were cultured in a 96well microplate with modified Eagle's medium containing $10 \%$ fetal bovine serum, $1 \%$ L-glutamine, $1 \%$ pyruvate, $1 \%$ nonessential amino acid, and $1 \%$ penicillin/streptomycin/neomycin in an initial density of $4 \times 10^{3}$ cells/well and were maintained at $37{ }^{\circ} \mathrm{C}$ in a humidified atmosphere of $95 \%$ air and $5 \% \mathrm{CO}_{2}$. After $24 \mathrm{~h}$, serial dilutions of the

(25) Pu, Y. C.; Hwu, J. R.; Su, W. C.; Shieh, D. B.; Tzeng, Y.; Yeh, C. S. J. Am. Chem. Soc. 2006, 128, 11606-11611.

(26) Sun, Y. G.; Mayers, B. T.; Xia, Y. N. Nano Lett. 2002, 2, 481-485

(27) Cook, J. A.; Mitchell, J. B. Anal. Biochem. 1989, 179, 1-7. 
$\mathrm{Au}_{3} \mathrm{Cu}_{1}$ nanocapsules or nanoshells with particle concentrations of $0.001,0.01,0.1,1.0,10.0,50.0,100.0$, and $200.0 \mu \mathrm{g} \mathrm{mL}^{-1}$ were added to the culture wells to replace the original culture medium with a final volume of $100 \mu \mathrm{L}$. Method II: $\mathrm{Au}_{3} \mathrm{Cu}_{1}$ nanocapsules or nanoshells with particle concentrations of 50.0, 100.0, and $200.0 \mu \mathrm{g} \mathrm{mL}^{-1}$ were coated on the 96-well microplate. Cells $\left(4 \times 10^{3}\right.$ cells/well $)$ were then added to the culture wells to replace the original culture medium with a final volume of $100 \mu \mathrm{L}$.

The cells were incubated with the nanoparticles for 6 or $24 \mathrm{~h}$ in both methods. Then, the culture medium was removed and replaced by $100 \mu \mathrm{L}$ of the new culture medium containing $10 \%$ WST- 1 reagent. The cells were then incubated for $1.5 \mathrm{~h}$ to allow formation of formazan dye at $37{ }^{\circ} \mathrm{C}$. Next, the culture medium in each well was centrifuged, to preclude potential interference of nanoparticles with the spectrophotometric measurement, and then transferred to an ELISA plate. The quantification determining cell viability was done using optical absorbance $(450 / 690 \mathrm{~nm})$ and an ELISA plate reader.

In Vitro MR Imaging. The experiments were done using a spectroscope (3T MRI Biospec; Bruker, Ettlingen, Germany). A gradient system mounted on the table of the $3 \mathrm{~T}$ magnet with an inner diameter of $6 \mathrm{~cm}$ and a maximal gradient strength of $1000 \mathrm{mT} \mathrm{m}^{-1}$ was used to yield high-resolution images. A quadrature coil with an inner diameter of $3.5 \mathrm{~cm}$ was used for RF transmission and reception. For in vitro MR images and both $T_{1}$ and $T_{2}$ measurements, all nanoshells and nanocapsules were dispersed in $5 \%$ agarose gel of various concentrations $\left(0.125,0.25,1.25,2.5\right.$, and $\left.5 \mathrm{mg} \mathrm{mL}^{-1}\right)$. The array was embedded in a phantom consisting of a tank of water to allow appropriate image acquisition. Acquired images had a matrix size of $256 \times 192$, a field of view of $60 \times 60 \mathrm{~mm}^{2}$, and a slice thickness of $6 \mathrm{~mm}$ yielding an in-plane resolution of $234 \mathrm{~mm}$ after image smoothing. Both $T_{1^{-}}$and $T_{2}$-weighted images were acquired using a multislice multiecho ( $T_{1}$-weighted) and fast spin echo ( $T_{2}$-weighted) sequence with a repetition time/echo time (TR/TE) of $472 / 9.4 \mathrm{~ms}$ and a number of averages (NEX) of 8 and TR/TE of 4500/65 ms and a NEX of 6 , respectively. $T_{1}$ value measurements were done using a multislice multiecho sequence with a TR of $6000 \mathrm{~ms}$, a TE of $8.7 \mathrm{~ms}$, and 45 inversion recovery points (TI from 13.3 to $6000 \mathrm{~ms}$ ). The field of view was $60 \times 60 \mathrm{~mm}^{2}$, the slice thickness was $6 \mathrm{~mm}$, and the image matrix was $128 \times 128$. This allowed for simultaneous imaging of 26 vials with $0.3 \mathrm{~mL}$ of contrast agent for each vial. An average signal of 50 voxels was evaluated for all TI values. $T_{2}$ value measurements were performed with a spin echo sequence of TR/TE of 4000/10.1 ms, 60 echo points of 60 , and a NEX of 5 . The field of view was $60 \times 60$ $\mathrm{mm}^{2}$, the slice thickness was $6 \mathrm{~mm}$, and the imaging plane was $256 \times$ 192.

In Vivo MR Imaging in Mice. In vivo MR images of the $\mathrm{Au}_{3} \mathrm{Cu}_{1}$ nanocapsules were evaluated in a BALB/c mice model. The mice were anesthetized using isoflurane and then given $\mathrm{Au}_{3} \mathrm{Cu}_{1}$ nanocapsules (20 $\mathrm{mg} \mathrm{kg}^{-1}$ ), dispersed in normal saline, via the tail vein. The images were acquired instantly and persisted for $2 \mathrm{~h}$. Images of the axial view had a field of view of $40 \times 40 \mathrm{~mm}^{2}$, a slice thickness of $1.5 \mathrm{~mm}$, a matrix size of $256 \times 192$, and a NEX of 3 . Images of coronal view had a field of view of $80 \times 40 \mathrm{~mm}^{2}$, a slice thickness of $1.5 \mathrm{~mm}$, a matrix size of $256 \times 128$, and a NEX of 5. $T_{1}$-weighted MR images had the following parameters: multislice multiecho with a TR/TE of $747.2 / 9.1 \mathrm{~ms}$ in the axial view and 500/8.6 $\mathrm{ms}$ in the coronal view. $T_{2}$-weighted MR images had the following parameters: fast spin echo with a TR/TE of $4682.2 / 62.0 \mathrm{~ms}$ in the axial view and 4500/62.0 ms in the coronal view.

Mouse Survival Analysis. Male BALB/c mice (age range: $8-12$ weeks old; weight: $28-30 \mathrm{~g}$ ) were purchased from the laboratory animal center of National Cheng Kung University (NCKU), Tainan, Taiwan. The animals were housed together in temperature- and humidity-controlled quarters $\left(25^{\circ} \mathrm{C} ; 50 \%\right.$ humidity) with a $12 / 12 \mathrm{~h}$ (light/dark) cycle and free access to food and water. Acquisition, care, use, and disposition of these mice conformed to the guidelines for the humane treatment of experimental animals established by NCKU Medical College. The mice were divided into groups of three, anesthetized using intraperitoneally injected acepromazine maleate (2 $\mathrm{mL} \mathrm{kg}^{-1}$ ) (Tech America, Elwood, KS), and injected with the $\mathrm{Au}_{3} \mathrm{Cu}_{1}$ nanocapsules with 2,20 , and $40 \mathrm{mg} \mathrm{kg}^{-1}$ via the tail vein, respectively.

\section{Results and Discussion}

Recently, we fabricated porous $\mathrm{Au}_{3} \mathrm{Cu}_{1}$ hollow nanostructures with an average diameter of $48.9 \pm 19.1 \mathrm{~nm}$ and a shell thickness of $5.8 \pm 1.8 \mathrm{~nm} .{ }^{28}$ Once the $\mathrm{Cu}$ nanoparticles were synthesized in 2-propanol by laser ablation, $\mathrm{HAuCl}_{4}$ (dehydrated) was added to $\mathrm{Cu}$ colloidal solution to yield $\mathrm{Au}_{3} \mathrm{Cu}_{1}$ nanoshells at room temperature. The particle peripheries appeared darker than their central portions, and the nanoshells were made of discrete particle domains, which indicated porous morphology. The porous nanoshells were composed of $\mathrm{Au}_{3}-$ $\mathrm{Cu}_{1}$ structures, determined by selected-area electron diffraction and XRD measurements, with low crystallinity. ${ }^{28}$ The $\xi$-potential measurements indicated that these $\mathrm{Au}_{3} \mathrm{Cu}_{1}$ hollow nanoparticles had a negative surface charge of $-18 \mathrm{mV}$, which could be further engineered to assemble with multilayer polyelectrolytes on their surfaces as nanocapsules. We conducted XANES measurements by taking advantage of the broadband nature of synchrotron radiation and tuning the excitation energy through an absorption threshold of interest. XANES reflects the energy dependence of the number of unoccupied states of the local electronic structure of the material. The oxidation state and local chemical environment at the site of the absorbing atom defined the shape and energy position of XANES spectra. This technique is well suited for studying systems with or without long-range order as well as for studying a dilute sample. The spectra also provide information about the oxidation state and local symmetry of the absorbing atomic center, and the edge positions $\left(E_{0}\right)$ are sensitive to the oxidation state of the metals. For $\mathrm{Au}_{3}-$ $\mathrm{Cu}_{1}$ nanoshells, the edge energy of $\mathrm{Au}_{3} \mathrm{Cu}_{1}$, relative to the $\mathrm{Au}$ foil, shifted slightly to lower energy $(-0.23 \mathrm{eV})$ at the $\mathrm{Au} \mathrm{L}_{\mathrm{III}}$ edge and increased significantly $(+6.88 \mathrm{eV})$ at the $\mathrm{Cu} \mathrm{K}$ edge (Figure 1). The small $E_{0}$ change at the $\mathrm{Au} \mathrm{L}_{\mathrm{III}}$ edge might correlate to the inner chemical property of $\mathrm{Au}$, while the large $E_{0}$ change at the $\mathrm{Cu}$ edge reflected its high oxidation state; here, $\mathrm{Cu}$ in $\mathrm{Au}_{3} \mathrm{Cu}_{1}$ can be assigned up to +3 . The oxidation states of copper normally exhibit as +1 and +2 , although some +3 complexes are known. $\mathrm{Cu}^{3+}$ has an electronic configuration of $\mathrm{d}^{8}$ with two unpaired electrons. Compared with $\mathrm{Gd}^{3+}$ (seven unpaired electrons), $\mathrm{Fe}^{3+}$ (five unpaired electrons), and $\mathrm{Mn}^{2+}$ (five unpaired electrons), paramagnetic $\mathrm{Cu}^{3+}$ ions do not have large magnetic moment. It is known that the relaxivity of an ion is related to the square of its electronic moment as well as to the square of its electronic spin. Cooperativity can be established by building up the individual spins to form significant magnetic moment. In a $\mathrm{Au}_{3} \mathrm{Cu}_{1}$ hollow nanostructure with an average diameter of $48.9 \mathrm{~nm}$ and shell thickness of 5.8 $\mathrm{nm}$, the number of copper atoms is roughly $498440 .^{29}$ Therefore, $\mathrm{Au}_{3} \mathrm{Cu}_{1}$ nanoshells are made of significant numbers of paramagnetic $\mathrm{Cu}^{3+}$ ions, resulting in an effectively superparamag-

(28) Hsiao, M. T.; Chen, S. F.; Shieh, D. B.; Yeh, C. S. J. Phys. Chem. B 2006 , $110,205-210$.

(29) The diameter and thickness of the $\mathrm{Au}_{3} \mathrm{Cu}_{1}$ hollow nanoparticles were 48.9 and $5.8 \mathrm{~nm}$, respectively. From $\mathrm{X}$-ray powder diffraction analysis, $\mathrm{Au}_{3} \mathrm{Cu}$ had a cubic phase in which $a=4.088$ A. Therefore, we calculated the volume of the shell for $\mathrm{Au}_{3} \mathrm{Cu}_{1}$ as $3.40 \times 10^{7} \AA^{3}$, giving the number of $\mathrm{Au}_{3} \mathrm{Cu}_{1}$ copper atoms to be 498440.65 following $3.40 \times 10^{7} \AA^{3} /(4.088$ $\AA)^{3}$. 
a.

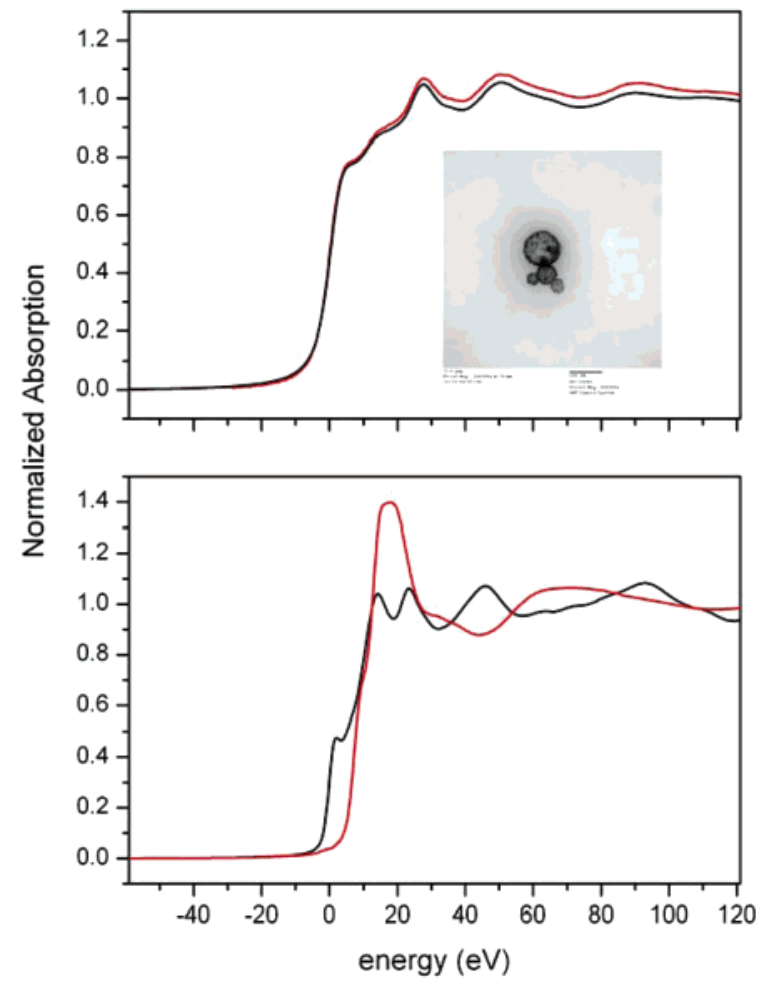

Figure 1. XANES spectra of $\mathrm{Au}_{3} \mathrm{Cu}_{1}$ nanoshells. All XANES were used to measure the (a) $\mathrm{Au} \mathrm{L}_{\text {III }}$ edge of $\mathrm{Au}_{3} \mathrm{Cu}_{1}$ nanoshells (red) and $\mathrm{Au}$ foil (black, $E_{0}=11919 \mathrm{eV}$ ) and the (b) $\mathrm{Cu} \mathrm{K}$ edge of $\mathrm{Au}_{3} \mathrm{Cu}_{1}$ nanoshells (red) and $\mathrm{Cu}$ foil (black, $E_{0}=8979 \mathrm{eV}$ ). The inset shows a transmission electron microscopy (TEM) image of $\mathrm{Au}_{3} \mathrm{Cu}_{1}$ hollow nanostructures. Additional $\mathrm{Au}_{3-}$ $\mathrm{Cu}_{1}$ nanoshells with a larger TEM view can also be seen in the Supporting Information, Figure S1.

netic effect. On the basis of the Solomon-BloembergenMorgan equations developed for solvent nuclear relaxation in the presence of paramagnetic species, ${ }^{30}$ we found that the innersphere proton relaxivity increases with an increase in the number of water molecules coordinated to the paramagnetic metal ion. That is, the longitudinal inner-sphere relaxation rate $\left(1 / T_{1}\right)$ is linearly proportional to the number of bound water molecules per metal ion. The tumbling rate $\left(1 / \tau_{\mathrm{R}}\right)$ of the intact paramagnetic substance also strongly affects the relaxivity. The rotational correlation time $\left(\tau_{\mathrm{R}}\right)$ determines the effective correlation time of proton relaxation and generally increases with increasing molecular weight. The maximum relaxivity is attained when the effective correlation time of proton relaxation equals the inverse proton Larmor frequency. Consequently, the rotational motion has to be slowed down to improve the efficiency of the contrast agents with increasing relaxivity. Given these properties, because of their higher surface area relative to their solid counterparticles, porous $\mathrm{Au}_{3} \mathrm{Cu}_{1}$ nanoshells with hollow interiors provide a greater number of inner-sphere water molecules subject to high accessibility and interaction between the water molecules and the $\mathrm{Au}_{3} \mathrm{Cu}_{1}$. The high degree of cooperativity resulting in significant magnetic moment, as well as the heavier weight of $\mathrm{Au}_{3} \mathrm{Cu}_{1}$ nanoshells compared to that of paramagnetic complexes, also possibly contributed enhanced bulk water relaxation, which gave rise to our first example of a bimetallic relaxation agent.

Currently, porous $\mathrm{Au}_{3} \mathrm{Cu}_{1}$ nanoshells can be used as nanocapsules to carry biomolecules for cell targeting and controlled

(30) Lauffer, R. B. Chem. Rev. 1987, 87, 901-927.

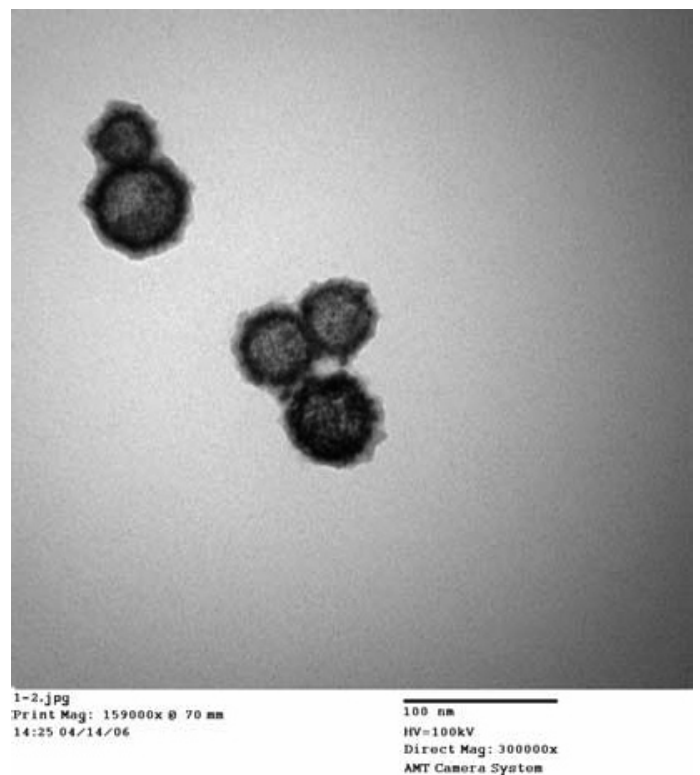

Figure 2. TEM image of $\mathrm{Au}_{3} \mathrm{Cu}_{1}$ nanocapsules showing polyelectrolyte shells.

drug release. The potential for being both an MR imaging agent and a capsule-type targeting moiety will also permit porous $\mathrm{Au}_{3}-$ $\mathrm{Cu}_{1}$ nanoshell systems to serve as multifunctional biological imaging probes. Because of its porous structure, an appropriate shield covering the nanoshells surface is required for safe delivery. The pores of $\mathrm{Au}_{3} \mathrm{Cu}_{1}$ nanoshells are irregularly shaped and, based on calculating the smallest diameter in each void, have a range of between 1 and $2 \mathrm{~nm}$. Biocompatible polyelectrolyte materials, PEI and PAA, are used on the particle surfaces that form polyelectrolyte multilayer nanocapsules. The layerby-layer templating of $\mathrm{Au}_{3} \mathrm{Cu}_{1}$ nanoshells to prepare $\mathrm{Au}_{3} \mathrm{Cu}_{1}$ nanocapsules was carried out by sequentially depositing PEI and PAA as building blocks on the $\mathrm{Au}_{3} \mathrm{Cu}_{1}$ nanoshell surfaces. The PEI provided a positively charged layer while the PAA formed the wrapping around the negatively charged layer over the first coating of the PEI using a layer-by-layer strategy. The three-layer polyelectrolytes (PEI/PAA/PEI) (shown in Figure 2 and Supporting Information, Figure S2), with PEI as the outermost layer in the polyelectrolyte shells, were deposited on the $\mathrm{Au}_{3} \mathrm{Cu}_{1}$ nanoshell surfaces; the polymer shell was $6.1 \pm$ 1.2-nm thick. The formation of $\mathrm{Au}_{3} \mathrm{Cu}_{1}$ nanocapsules relies on the interaction between oppositely charged polymers and is reproducible using the layer-by-layer strategy. The resulting polyelectrolyte-coated $\mathrm{Au}_{3} \mathrm{Cu}_{1}$ nanocapsules can be dispersed in 2-propanol, $\mathrm{H}_{2} \mathrm{O}$, and phosphate buffer.

We then evaluated in vitro spin-lattice relaxation time $\left(T_{1}\right)$ weighted images and spin-spin relaxation time $\left(T_{2}\right)$ weighted images in $0.5 \%$ agarose gel for $\mathrm{Au}_{3} \mathrm{Cu}_{1}$ nanocapsules $\left(\mathrm{Au}_{3} \mathrm{Cu}_{1}\right.$ coated with PEI/PAA/PEI) and $\mathrm{Au}_{3} \mathrm{Cu}_{1}$ nanoshells (not coated with polymers) with different concentrations: $0(0.5 \%$ agarose gel only), $0.125,0.25,1.25,2.50$, and $5.00 \mathrm{mg} \mathrm{mL}^{-1}$ (Figure 3).

Adding $\mathrm{Au}_{3} \mathrm{Cu}_{1}$ nanocapsules to the agarose gel brightened the $T_{1}$ image and enhanced the $T_{1}^{-1}$ of water protons. The $T_{1^{-}}$ weighted MR signal intensity continuously increased by $\sim 89 \%$ with increasing $\mathrm{Au}_{3} \mathrm{Cu}_{1}$ nanocapsule concentrations from 0 to $5.00 \mathrm{mg} \mathrm{mL}^{-1}$; however, using $\mathrm{Au}_{3} \mathrm{Cu}_{1}$ nanoshells resulted in only $\sim 26 \%$ increases in $T_{1}$ image intensity (Figure $4 \mathrm{a}$ ). The 
a.

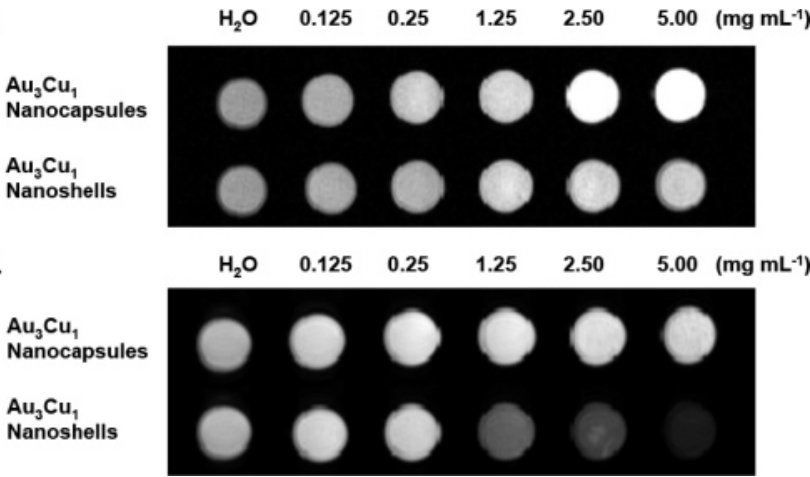

Figure 3. $\mathrm{MR}$ in vitro assays of $\mathrm{Au}_{3} \mathrm{Cu}_{1}$ nanocapsules and nanoshells. (a) Multislice multiecho $T_{1}$-weighted images of $\mathrm{Au}_{3} \mathrm{Cu}_{1}$ nanocapsules and nanoshells in water containing $0.5 \%$ agarose gel at $125.3 \mathrm{MHz}$ (3T MR system) $(\mathrm{TR} / \mathrm{TE}=472 \mathrm{~ms} / 9.4 \mathrm{~ms})$. (b) Fast spin echo $T_{2}$-weighted images of $\mathrm{Au}_{3} \mathrm{Cu}_{1}$ nanocapsules and nanoshells in water containing $0.5 \%$ agarose gel at $125.3 \mathrm{MHz}$ (3T MR system) (TR/TE $=4500 \mathrm{~ms} / 65 \mathrm{~ms})$. The images were taken using the designed sequences with a matrix size of $256 \times 192$, a field of view of $60 \times 60 \mathrm{~mm}^{2}$, and a slice thickness of $6 \mathrm{~mm}$.

concentration-dependent proton longitudinal relaxivities, $r_{1}$, of $\mathrm{Au}_{3} \mathrm{Cu}_{1}$ nanocapsules and $\mathrm{Au}_{3} \mathrm{Cu}_{1}$ nanoshells were determined at $125.3 \mathrm{MHz}$ (3T MR system). The relaxivities were estimated in terms of molar relaxivity $\left(\mathrm{mM}^{-1} \mathrm{~s}^{-1}\right)$ based on the number of nanoparticles per mM. For example, $0.25 \mathrm{mg} \mathrm{mL}^{-1}$ corresponds to $7.67 \times 10^{-7} \mathrm{mM}$, where the number of $\mathrm{Au}_{3} \mathrm{Cu}_{1}$ units in a nanoshell particle is calculated relative to nanoshell dimension. ${ }^{31}$ The proton relaxivities were as significantly large as $3.0 \times 10^{4} \mathrm{mM}^{-1} \mathrm{~s}^{-1}\left(\mathrm{Au}_{3} \mathrm{Cu}_{1}\right.$ nanocapsules $)$ and $2.3 \times 10^{4}$ $\mathrm{mM}^{-1} \mathrm{~s}^{-1}\left(\mathrm{Au}_{3} \mathrm{Cu}_{1}\right.$ nanoshells), possibly because of a high degree of cooperativity but the nanocapsules had slightly larger $r_{1}$ relaxivity values than the nanoshells did. This level of relaxivity has also been observed in Gd-based nanoparticles. ${ }^{19}$ Interestingly, in the $T_{2}$-weighted imaging sequences for both the nanocapsules and the nanoshells, the intensity of the MR images was increased at the low concentration of $0.125 \mathrm{mg}$ $\mathrm{mL}^{-1}\left(3.84 \times 10^{-7} \mathrm{mM}\right)$, and then the signal continuously decreased with increasing concentration, particularly in the nanoshells, which showed a marked darkening of MR images. The MR signal intensities increased by $\sim 8$ and $\sim 11 \%$ at 0.125 $\mathrm{mg} \mathrm{mL} \mathrm{m}^{-1}$ and then dropped by $\sim 6$ and $\sim 76 \%$ at the high concentration of $5.0 \mathrm{mg} \mathrm{mL}^{-1}\left(1.53 \times 10^{-5} \mathrm{mM}\right)$ for nanocapsules and nanoshells, respectively (Figure 4b). The image intensities all refer to $\mathrm{H}_{2} \mathrm{O}(0.5 \%$ agarose gel without adding nanomaterials). The $T_{2}$-weighted images show that intensity increased at low concentration and that the $T_{2}$-lowering effect and signal decreases dominated at high concentration. The transverse $r_{2}$ relaxivities derived were $2.39 \times 10^{5}$ for nanocapsules and $1.82 \times 10^{6} \mathrm{mM}^{-1} \mathrm{~s}^{-1}$ for nanoshells. The strong proton dephasing effect, $T_{2}$, was surprising in the nanoshells. Compared to $\mathrm{Au}_{3} \mathrm{Cu}_{1}$ nanocapsules, perhaps $\mathrm{Au}_{3} \mathrm{Cu}_{1}$ nanoshells not coated with polymers provide a substantial water exchange between interior and exterior spheres that results in a shorter residence lifetime, $\tau_{\mathrm{m}}$, of coordinated water and, therefore, give a larger $r_{2}$ relaxivity. On the other hand, the molecular weights of contrast agents would affect the $r_{1}$ relaxivity. According to the Debye-Stokes equation, the rotational correlation time $\left(\tau_{\mathrm{R}}\right)$

(31) The particle concentration of $\mathrm{Au}_{3} \mathrm{Cu}_{1}$ can be obtained as follows: the molecular weight of a $\mathrm{Au}_{3} \mathrm{Cu}_{1}$ molecule is $654.45 \mathrm{~g} \mathrm{~mol}^{-1}$ and each nanocapsule has $4.98 \times 10^{5} \mathrm{Au}_{3} \mathrm{Cu}_{1}$ particles. Taking $0.25 \mathrm{mg} \mathrm{mL} \mathrm{m}^{-1}$ of $\mathrm{Au}_{3} \mathrm{Cu}_{1}$ nanocapsules as an example, the corresponding particle concentration is $7.67 \times 10^{-7} \mathrm{mM}$ from the calculation of $(0.25 / 654.45) / 4.98 \times 10^{5}$ a.

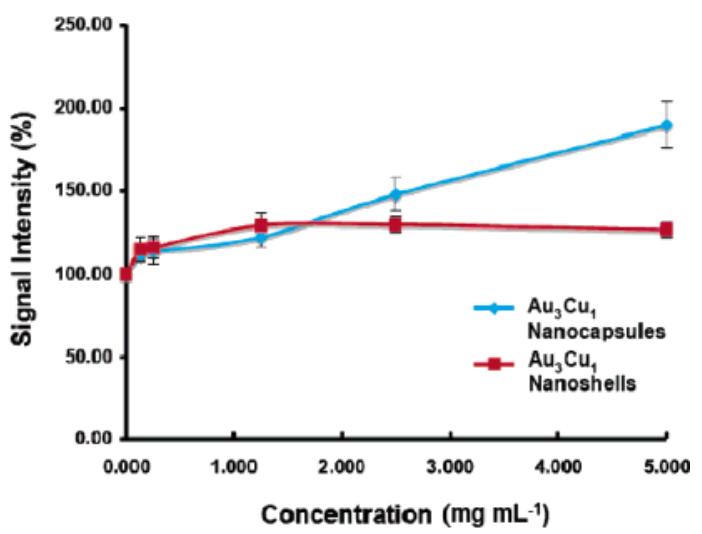

b.

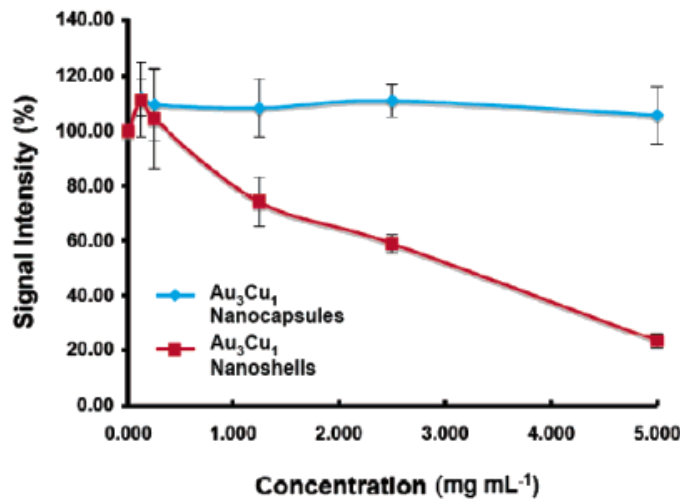

Figure 4. In vitro MRI intensity plots of (a) $T_{1}$ - and (b) $T_{2}$-weighted signals in $\mathrm{H}_{2} \mathrm{O} / 0.5 \%$ agarose gel containing increasing concentrations of $\mathrm{Au}_{3} \mathrm{Cu}_{1}$ nanocapsules (blue) and nanoshells (red).

is proportional to the third power of the hydrodynamic radius $\left(r_{\text {eff }}\right)$ and the $r_{\text {eff }}{ }^{3}$ is proportional to the molecular weights of the contrast agents. ${ }^{32}$ Hence, the $r_{1}$ of the contrast agents would increase as the molecular weight increased. Polymer-coated $\mathrm{Au}_{3^{-}}$ $\mathrm{Cu}_{1}$ nanocapsules are heavier than $\mathrm{Au}_{3} \mathrm{Cu}_{1}$ nanoshells and are expected to have a slower tumbling rate, which might have a greater effect on $T_{1}$ relaxation efficacy. However, a shorter $\tau_{\mathrm{m}}$ leads to a higher $r_{1}$ as well as $r_{2}$ relaxivity for $\mathrm{Au}_{3} \mathrm{Cu}_{1}$ nanoshells. Thus, the strong $T_{2}$-lowering effect observed in $\mathrm{Au}_{3}$ $\mathrm{Cu}_{1}$ nanoshells might have caused, to a certain degree, the signal increase from the $T_{1}$-lowering effect to be overcome. However, the increased intensity leading to bright contrast at lower concentrations (e.g., 0.125 and $0.25 \mathrm{mg} \mathrm{mL}^{-1}$ ) in $T_{2}$-weighted images is interesting and remains to be explained. Recently, Cheon et al. reported the particle size effect on the MR signals for iron oxide nanocrystals, where the $T_{2}$-weighted MR signal intensity continuously decreased as the particle size increased from 4 to $12 \mathrm{~nm} .{ }^{33}$ Although the laser ablation employed here can readily generate spherical nanoparticles, the particles formed in this way usually suffer from inhomogeneous particle sizes $(48.9 \pm 19.1 \mathrm{~nm})$. Size exclusion was then conducted by a simple centrifugation process (3000 rpm, $3 \mathrm{~min}$ ). The particles obtained from the supernatant of the colloidal solution displayed smaller average diameter size but still exhibited a broad size distribution $(42.1 \pm 17.4 \mathrm{~nm})$. However, it is interesting that we were able to collect the fragments resulting from the collapse of the $\mathrm{Au}_{3} \mathrm{Cu}_{1}$ nanoshells by addition of more $\mathrm{HAuCl}_{4}(1.3 \times$

(32) Toth, E.; Helm, L.; Merbach, A. E. Contrast Agents I 2002, 221, 61-101.

(33) Jun, Y.-W.; Huh, Y.-M.; Choi, J.-S.; Lee, J.-H.; Song, H.-T.; Kim, S.; Yoon, S.; Kim, K.-S.; Shin, J.-S.; Suh, J.-S.; Cheon, J. J. Am. Chem. Soc. 2005, $127,5732-5733$. 
$10^{-6} \mathrm{~mol}$ ) into $\mathrm{Cu}$ colloidal solution. The fragmentation of $\mathrm{Au}_{3^{-}}$ $\mathrm{Cu}_{1}$ nanoshells into nanoparticles retaining $\mathrm{Au}_{3} \mathrm{Cu}_{1}$ identity had particle size of $8.3 \pm 1.2 \mathrm{~nm}$ and exhibited some degree of aggregation (Supporting Information, Figure S3). These $\mathrm{Au}_{3}-$ $\mathrm{Cu}_{1}$ fragments had $r_{1}$ and $r_{2}$ relaxivities of $1.0 \times 10^{4}$ and $1.8 \times$ $10^{4} \mathrm{mM}^{-1} \mathrm{~s}^{-1}$, respectively, showing less relaxivity than those of nanoshells and nanocapsules. Such a nanoshell collapse has been observed in the replacement reaction of $\mathrm{Ag}$ nanostructures with $\mathrm{HAuCl}_{4}$, accompanied with a dealloying process by the conversion of $\mathrm{Au}-\mathrm{Ag}$ alloy into $\mathrm{Au} .{ }^{34}$ Herein, the fragments remained as alloy composition (i.e., $\mathrm{Au}_{3} \mathrm{Cu}_{1}$ ). Notably, a parallel experiment was performed to study $\mathrm{MR}$ in vitro $T_{1^{-}}$and $T_{2^{-}}$ weighted images for Au nanoparticles $(13 \mathrm{~nm})$ and showed no effect on relaxivity.

$\mathrm{Au}_{3} \mathrm{Cu}_{1}$ nanocapsules and nanoshells show promising MR signal enhancement as contrast agents. It is necessary to evaluate whether these nanomaterials have any deleterious biological properties. Cell viability experiments were conducted on a Vero cell line (monkey kidney cell line) using a WST-1 (tetrazolium salt) assay $^{27}$ (Roche Diagnostics, Mannheim, Germany), a wellestablished method. This assay is based on measuring the darkred formazan formed by metabolically active cells; the quantity of formazan is in direct proportion to the number of viable cells after their exposure to WST-1. Both $\mathrm{Au}_{3} \mathrm{Cu}_{1}$ nanocapsules and nanoshells were delivered over a range of dosages $(0-200 \mu \mathrm{g}$ $\left.\mathrm{mL}^{-1}\right)$. The assay showed that the level of cell damage was dose-dependent. Both the nanocapsules and the nanoshells were biocompatible in vitro at all dosages between $0.1 \mathrm{ng} \mathrm{mL}^{-1}$ and $10 \mu \mathrm{g} \mathrm{mL}^{-1}$ (Supporting Information, Figure S4a). Toxicity increased and cell survival decreased as the dosage increased. At $200 \mu \mathrm{g} \mathrm{mL}^{-1}$, viability dropped to about $15 \%$ after $24 \mathrm{~h}$ of treatment (Supporting Information, Figure S4b) using Method I, where the nanoshells or nanocapsules covered the cells. The excess amount of the hollow nanoparticles coverage at high dosage may not be tolerated by the cells. We hypothesized that the nanoshells and nanocapsules reduced cell viability because they occupied the space for cell growth in the culture wells. To confirm whether cell viability was affected by the intrinsic nature of the hollow nanomaterials and not their weight or the space they occupied, we conducted an alternative examination by first coating the culture plate with nanoshells or nanocapsules and then adding cells over nanoparticles for incubation (Method II). Cell viability was higher using Method II (Figure 5). $\mathrm{Au}_{3} \mathrm{Cu}_{1}$ nanocapsules were more biocompatible than nanoshells: $61 \%$ for nanocapsules versus $43 \%$ for nanoshells after $6 \mathrm{~h}$ of incubation (Figure 5a) and 61\% for nanocapsules versus $50 \%$ for nanoshells after $24 \mathrm{~h}$ of incubation at $200 \mu \mathrm{g} \mathrm{mL}^{-1}$ (Figure $5 b)$. Our findings indicate that cell viability was affected by dose-dependent toxicity and, at least at the highest dosage, which assay method was used.

We next examined the potential of $\mathrm{Au}_{3} \mathrm{Cu}_{1}$ nanocapsules (coated with PEI/PAA/PEI) as contrast agents in a series of MR imaging studies using $\mathrm{BALB} / \mathrm{c}$ mice. We injected into the tail vein of each mouse (average body weight, $28 \mathrm{~g}$ ) $\mathrm{Au}_{3} \mathrm{Cu}_{1}$ nanocapsules $\left(100 \mu \mathrm{L}, 5.0 \mathrm{mg} \mathrm{mL}^{-1}\right)$ corresponding to $20 \mathrm{mg}$ $\mathrm{kg}^{-1}$. In general, the favorable dosages were $50 \mathrm{mg} \mathrm{kg}^{-1}$ for $\mathrm{Gd}^{3+}$ paramagnetic agents, such as $\mathrm{Gd}^{3+}$-DTPA (Magnevist), $\mathrm{Gd}^{3+}$-DOPA (Dotarem), Gd ${ }^{3+}$-DTPA-BMA (OmniScan), and $\mathrm{Gd}^{3+}-\mathrm{HP}-\mathrm{DO}_{3}$ (ProHance), and 5-30 $\mathrm{mg} \mathrm{kg}^{-1}$ for iron oxide-

(34) Sun, Y.; Xia, Y. J. Am. Chem. Soc. 2004, 126, 3892-3901.
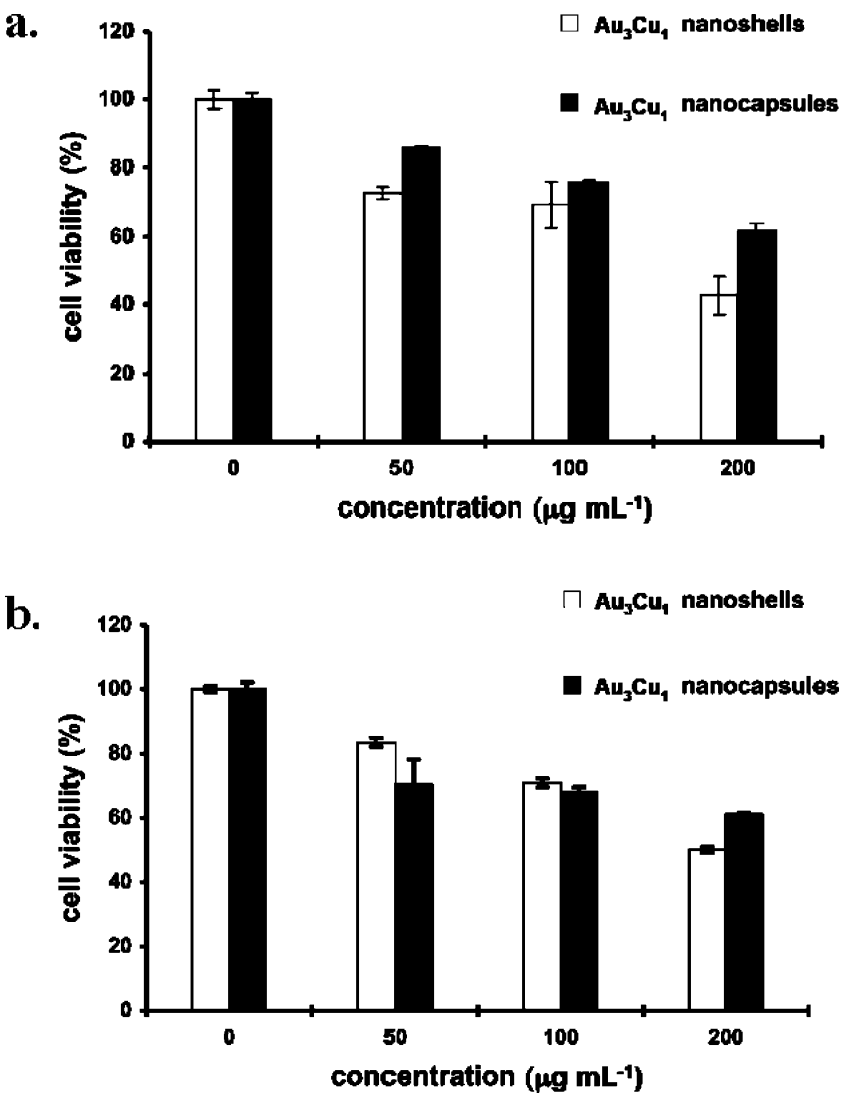

Figure 5. Biocompatibility of the $\mathrm{Au}_{3} \mathrm{Cu}_{1}$ nanoshells and $\mathrm{Au}_{3} \mathrm{Cu}_{1}$ nanocapsules using Method II. The biocompatibility was analyzed using a WST-1 assay. First, various dosages $\left(50,100,200 \mu \mathrm{g} \mathrm{mL}^{-1}\right)$ of nanoshells (white column) or nanocapsules (black column) were coated on the microplate. Next, Vero cells were added and incubated for (a) $6 \mathrm{~h}$ and (b) $24 \mathrm{~h}$.

based superparamagnetic agents. We monitored their progressive $T_{1}$ - and $T_{2}$-weighted imaging events at the $3 \mathrm{~T}$ magnetic field, and all the images were referred to fish oil for the imaging process. Pre- and post-contrast images showed that $\mathrm{Au}_{3} \mathrm{Cu}_{1}$ nanocapsules increased signal intensity in the cardiac area (Figure 6a). In $T_{1}$-weighted images, immediately after the injection (post $0 \mathrm{~h}$ ), the region of the cardiac chamber was brighter in axial and coronal views. After $2 \mathrm{~h}$ of circulation, the heart area appeared brighter. Color mapping of the identical MR images also provided evidence of MR signal changes: the light blue color in the cardiac region expanded $2 \mathrm{~h}$ after the injection. We also took anatomic $T_{2}$-weighted images of mice (Figure 6b). Interestingly, the $T_{2}$-weighted imaging shows that the $\mathrm{Au}_{3} \mathrm{Cu}_{1}$ nanocapsules brightly lit the cardiac region and the blood vessels of the liver and that the signal level increased for $2 \mathrm{~h}$ after the injection. $\mathrm{Au}_{3} \mathrm{Cu}_{1}$ nanocapsules enhanced the heart chamber images immediately and increasingly enhanced the images of the cardiac region for $2 \mathrm{~h}$. In the liver region, the images of the vessels were significantly enhanced, and the vessel branches appeared clearly $2 \mathrm{~h}$ postinjection. The coronal views also showed that $\mathrm{Au}_{3} \mathrm{Cu}_{1}$ nanocapsules provided positive contrast images. Once again, color maps of the $T_{2}$-weighted images display the imaging difference: the signal intensity and vessel visualization increased for $2 \mathrm{~h}$ in the thorax region (white arrow) and liver area (red arrow). The in vivo experiments indicated that $\mathrm{Au}_{3} \mathrm{Cu}_{1}$ nanocapsules not only have potential as positive-contrast agents, but also are quite effective for use in $\mathrm{MR}$ angiography as blood-pool agents. We found that $\mathrm{Au}_{3} \mathrm{Cu}_{1}$ 


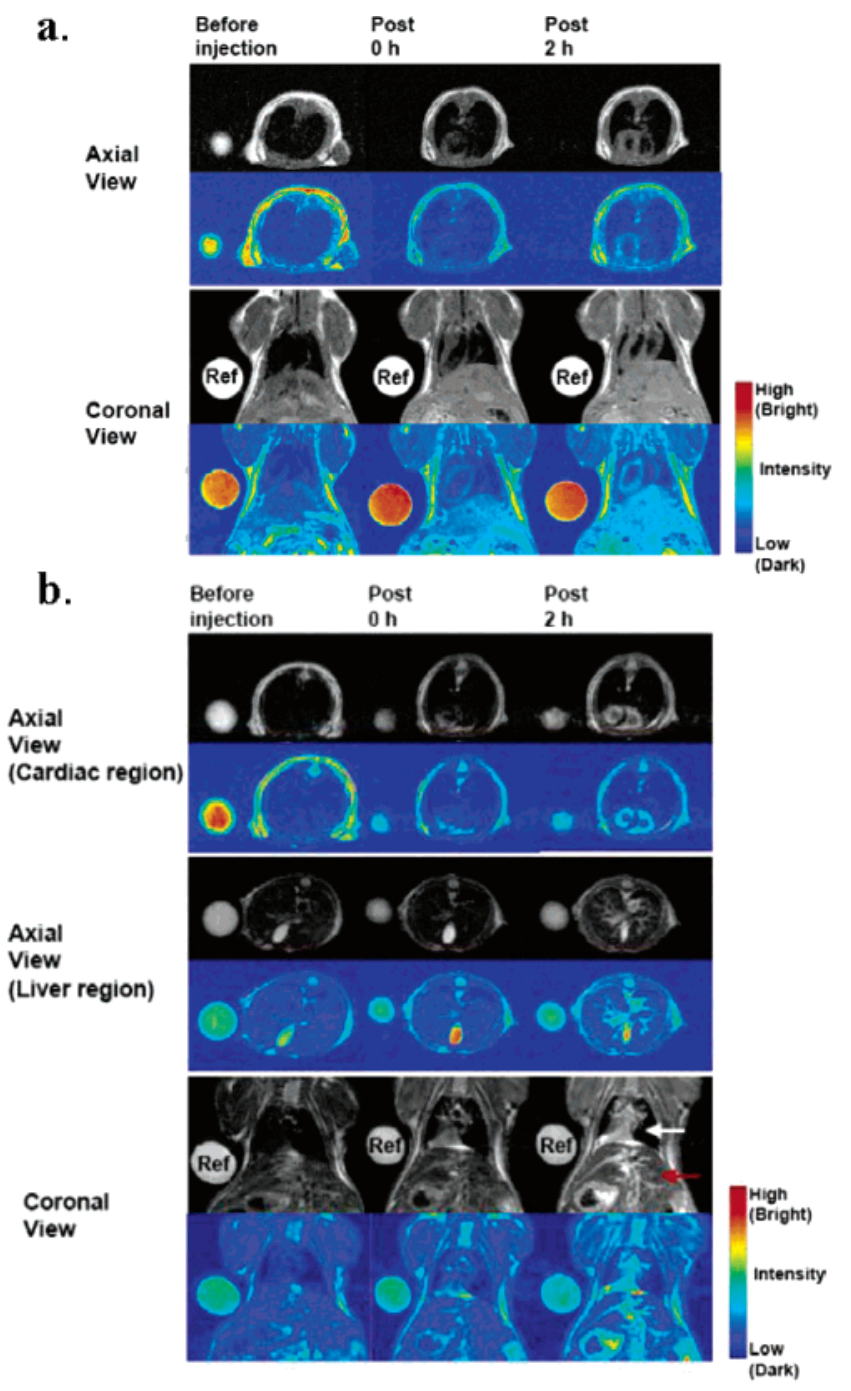

Figure 6. In vivo progressive MRI events and color maps. (a) $T_{1}$-weighted and (b) $T_{2}$-weighted images of male BALB/c mice at the indicated temporal points (pre-injection, immediately postinjection, and $2 \mathrm{~h}$ postinjection) in this experiment with $\mathrm{Au}_{3} \mathrm{Cu}_{1}$ nanocapsules. The arrows in (b) indicate the increase in signal intensity and show visualized vessels for the thorax and liver regions in $T_{2}$-weighted images (coronal view).

agents resulted in brighter in vivo $T_{2}$ MR imaging. In vitro $T_{2^{-}}$ weighted imaging demonstrated that phantom images lightened up at lower concentrations $\left(0.125\right.$ and $\left.0.25 \mathrm{mg} \mathrm{mL}^{-1}\right)$ and then consistently decayed as the concentration increased. The blood volume of a 28 -g mouse is approximately $2.0 \mathrm{~mL}$. Hence, each mouse's blood diluted a dose of $20 \mathrm{mg} \mathrm{kg}^{-1}$ to $0.25 \mathrm{mg} \mathrm{mL}^{-1}$. As the mice were injected with the $\mathrm{Au}_{3} \mathrm{Cu}_{1}$ nanocapsules, the nanocapsules would be perfused into the organs with the circulation, and the concentration of the targeting area would be lower than $0.25 \mathrm{mg} \mathrm{mL}^{-1}$.

Because the full application of these nanoshell materials requires careful attention to their toxicological impact, we further evaluated their in vivo dose-dependent acute toxic effects. Male $\mathrm{BALB} / \mathrm{c}$ mice (weight range: $28-30 \mathrm{~g}$ ) were divided into three groups of six mice that were given different doses: 2, 20, and $40 \mathrm{mg} \mathrm{kg}^{-1}$ of $\mathrm{Au}_{3} \mathrm{Cu}_{1}$ nanocapsules, respectively. Thirty days postinjection, the viability rates for the groups were $100 \%$ for the $2 \mathrm{mg} \mathrm{kg}^{-1}$ group, $83 \%$ for the $20 \mathrm{mg} \mathrm{kg}^{-1}$ group, and $67 \%$ for the $40 \mathrm{mg} \mathrm{kg}^{-1}$ group (Figure 7). These results suggested that $\mathrm{Au}_{3} \mathrm{Cu}_{1}$ nanocapsules were not an immediate danger for

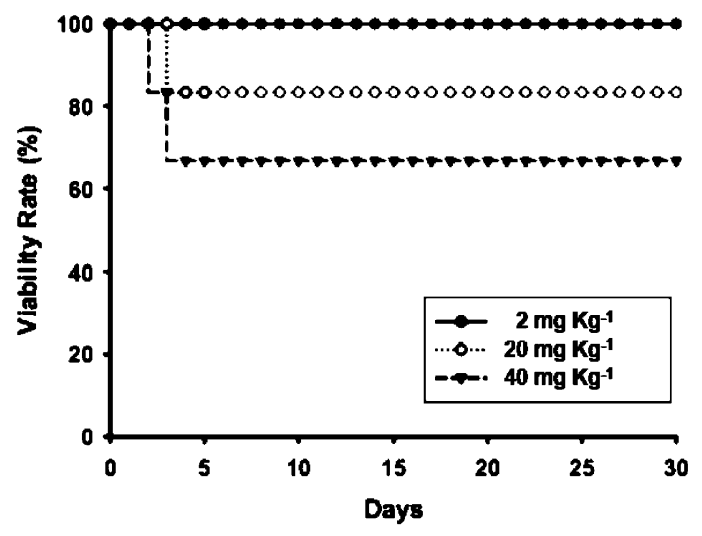

Figure 7. Survival rate of male BALB/c mice. The mice (weight: $28-30$ g) were injected with the indicated doses of $\mathrm{Au}_{3} \mathrm{Cu}_{1}$ nanocapsules. Survival was inversely related to the dose.

the mice when using 2 or $20 \mathrm{mg} \mathrm{kg}^{-1}$. We also collected urine from mice $3 \mathrm{~h}$ postinjection and, using inductively coupled plasma analysis, determined the levels of both $\mathrm{Cu}$ and $\mathrm{Au}$. The results suggested that $\mathrm{Au}_{3} \mathrm{Cu}_{1}$ nanocapsules were not retained in the body. Efficient excretion is an important safety consideration, especially if repeat use is contemplated. In fact, the MR imaging signal vanished $4 \mathrm{~h}$ postinjection. For the copper-related nanoparticles, it is worth mentioning that the toxicological studies of the copper particles in vivo indicated the nanocopper with size of $23.5 \mathrm{~nm}$ as moderately toxic (toxicity class 3 ). ${ }^{35}$ Based on animal experiments, the $\mathrm{LD}_{50}$ for copper nanoparticles $(23.5 \mathrm{~nm})$ used in experiments on mice is $413 \mathrm{mg} \mathrm{kg}^{-1}$. LD $\mathrm{LD}_{50}$, used to measure the acute toxicity of a material, is defined as the amount of a material, given all at once, resulting in the death of $50 \%$ of a group of test animals.

Finally, we synthesized and analyzed a porous bimetallic Au/ $\mathrm{Ag}$ nanoshell with the same hollow nanostructure and large surface area as the $\mathrm{Au}_{3} \mathrm{Cu}_{1}$ nanoshells. Porous $\mathrm{Au} / \mathrm{Ag}$ nanoshells were synthesized using a galvanic replacement reaction method with $\mathrm{Ag}$ nanoparticles and $\mathrm{HAuCl}_{4}$ solution, as previously described. ${ }^{26}$ The $\mathrm{Au} / \mathrm{Ag}$ hollow spheres had an average diameter of $53.23 \pm 14.66 \mathrm{~nm}$, and the shell was $7.35 \pm 3.50 \mathrm{~nm}$ thick. EDX analysis of these nanoshells showed that the atomic ratio of $\mathrm{Au} / \mathrm{Ag}=7 / 3$ (Supporting Information, Figure S5). XANES measurements indicated that the edge energies of $\mathrm{Au}$ in $\mathrm{Au}_{7^{-}}$ $\mathrm{Ag}_{3}$, relative to $\mathrm{Au}$ foil, shifted slightly $(+0.2 \mathrm{eV})$ at the $\mathrm{Au}$ $\mathrm{L}_{\mathrm{III}}$ edge and decreased a little $(-1.5 \mathrm{eV})$ at the $\mathrm{Ag} \mathrm{K}$ edge (Supporting Information, Figure S6). The small $E_{0}$ change at the $\mathrm{Au} \mathrm{L}_{\mathrm{III}}$ edge might correlate with the chemical inner property of $\mathrm{Au}$, and the slightly larger $E_{0}$ change at the $\mathrm{Ag} K$ edge indicated that its oxidation state did not change significantly. XANES results suggested that $\mathrm{Au}_{7} \mathrm{Ag}_{3}$ nanoshells likely contribute no comparable magnetic moment and are not suitable candidates for MR imaging. In vitro $T_{1^{-}}$and $T_{2}$-weighted measurements provided image evidence that $\mathrm{Au}_{7} \mathrm{Ag}_{3}$ nanoshells had no effect on relaxivity or image intensity when compared to the effect of pure $\mathrm{H}_{2} \mathrm{O}$ (Figure 8).

\section{Conclusion}

Because of the anomalously high oxidation state of copper, $\mathrm{Au}_{3} \mathrm{Cu}_{1}$ hollow nanostructures are believed to be the first

(35) Chen, Z.; Meng, H.; Xing, G.; Chen, C.; Zhao, Y.; Jia, G.; Wang, T.; Yuan, H.; Ye, C.; Zhao, F.; Chai, Z.; Zhu, C.; Fang, X.; Ma, B.; Wan, L. Toxicol. Lett. 2006, 163, 109-120. 


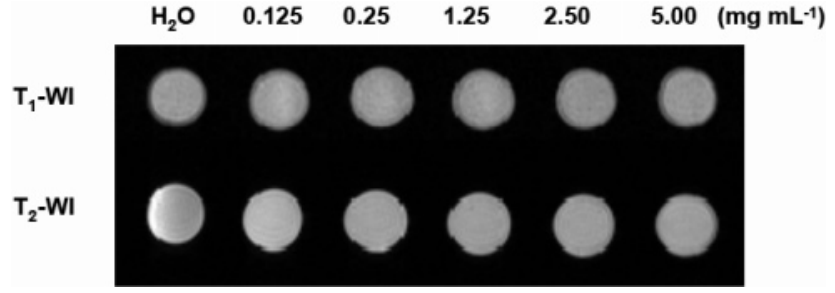

Figure 8. $\mathrm{MR}$ in vitro assays of $\mathrm{Au}_{7} \mathrm{Ag}_{3}$ nanoshells. Multislice multiecho $T_{1}$-weighted images with a TR/TE of $472 \mathrm{~ms} / 9.4 \mathrm{~ms}$ and fast spin echo $T_{2}$-weighted images with a TR/TE of $4500 \mathrm{~ms} / 65 \mathrm{~ms}$ for $\mathrm{Au}_{7} \mathrm{Ag}_{3}$ nanoshells in water containing $0.5 \%$ agarose gel operated at $125.3 \mathrm{MHz}$. The images were taken using the designed sequences with a matrix size of $256 \times 192$, a field of view of $60 \times 60 \mathrm{~mm}^{2}$, and a slice thickness of $6 \mathrm{~mm}$.

bimetallic MR contrast agents. $\mathrm{Au}_{3} \mathrm{Cu}_{1}$ nanocapsules enhanced signal contrast not only in $T_{1}$-weighted imaging, but also in $T_{2^{-}}$ weighted imaging at lower doses. The increased brightness of $T_{2}$-weighted MR images has resulted in the potential development of this agent for MR angiography. Although the mechanism of the contrast effect of this agent has yet to be fully understood, we believe that the cooperativity originating from the form of the nanoparticles and the large surface area of the water, because of porous hollow morphology of the nanoparticle, are primarily involved. Furthermore, the amine groups on the outermost PEI polymer shell of the nanocapsules, which further provide surface modification for the attachment of biological signals, suggest great potential for use in multifunctional composite capsules as functional carriers and imaging agents. Overall, these results might lead to the creation of other nonGd- and non-iron oxide-based bimetallic contrast agents.

Acknowledgment. We thank Professor Ching-Po Lin for valuable discussions. This study was supported by the National Science Council of Taiwan.

Supporting Information Available: TEM images of $\mathrm{Au}_{3} \mathrm{Cu}_{1}$ nanoshells and fragments, $\zeta$-potential values of the $\mathrm{Au}_{3} \mathrm{Cu}_{1}$ nanoshells consecutively coated with polyelectrolytes, the biocompatibility of the $\mathrm{Au}_{3} \mathrm{Cu}_{1}$ nanoshells and nanocapsules, SEM image and EDS analysis of $\mathrm{Au}_{7} \mathrm{Ag}_{3}$, and XANES measurements of $\mathrm{Au}_{7} \mathrm{Ag}_{3}$. This material is available free of charge via the Internet at http://pubs.acs.org.

JA0672066 